\title{
The Role of Strategy Towards Business Performance in Hijab Small Businesses
}

\author{
Suaibatul Aslamiyah and Rahmat Agus Santoso \\ Management Study Program, Faculty of economics and business, Universitas Muhammadiyah Gresik, Gresik, \\ Indonesia. \\ *Corresponding author email: suaibatul.aslamiyah@umg.ac.id
}

\begin{abstract}
This research is to describe and explain the role of the strategies used and their effects in improving business performance in the Azky Collection hijab small business in Melirang Wetan Village, Bungah District, Gresik Regency. This research Methodology uses a case study approach with qualitative descriptive research methods. The results show that a strategy that focuses on changing consumer tastes and carrying out several innovations has a direct role in maintaining and improving business performance at Azky Collection, as evidenced by an increase in the number of sales that continue to increase. Conclusion - The strategy used by Azky Collection is a focus differentiation strategy that can be seen in the sales results that experience an increase every year. This research contributes to the application of strategy and performance management in small businesses (SMEs), as well as the religious value that exists in hijab. Research limits - Research is only conducted in 1 (one) small business (UKM), the next research can be done by comparing with several other small businessess.
\end{abstract}

Keywords: Hijab, Strategy, Performance, SMEs

\section{INTRODUCTION}

The hijab is used to emphasize issues of ethics, law, the security of the community where the verse was revealed, as well as the affirmation of the formation of a person's diverse identity. However, in its development, the use of the veil has undergone a significant shift in meaning. The hijab does not only function as a symbol of religious identity but is broader in terms of cultural, social, political, economic as well as fashion or fashion. This course makes the hijab not only a diverse identity but also a cultural identity. This kind of symptom can easily be found in social life [1]

Changes in the use of the hijab, which are reflected in changes in fashion or developing trends, are input for entrepreneurs in examining opportunities from changes in the external environment for the continuity of their business. To always be able to meet consumer needs and take advantage of opportunities that arise, entrepreneurs must formulate and implement business strategies well, clearly, and with direction.

From a historical perspective, most of the research on the business-performance strategy relationship is based on studies of western companies in developed countries, especially the United States [2]. Therefore, as a new research gap, the researcher examines the business-performance strategy by linking it to a cultural product, which indicates spiritual development or in this case the veil, which means expressing values and meanings to the wearer, in practice in developing countries like
Indonesia, and the right strategy to accommodate these changes.

Azky Collection is a small hijab business that can continuously improve its performance when there are changes in consumer desires. At present, the visible change based on the phenomenon is the shift in the hijab fashion from initially tending to be standard (not covering the hips and tends to be short) to Hijab syar'i (covering the hips and tends to be long). The making of the hijab with due regard to changing consumer desires is a strategy used by the Azky Collection in improving its performance which shows a significant increase. The research objective was to describe and explain the role of the strategies used and their effects in improving business performance in the small business of the Azky Collection hijab in Melirang Wetan Village, Bungah District, Gresik Regency.

\section{LITERATURE REVIEW 2.1 Hijab}

The hijab is a kind of bracket covering the head, face, and chest [3] The Hijab is compulsory for Muslim women. This is written in the Koran, and there is no need to argue with it. Therefore, every Muslim woman feels she is doing worship when she wears the hijab. In worship, we are dealing with God and not with others, so sincerity, fortitude, patience, and a firm intention to carry out God's commands are the main considerations [4]This is explained in one of 
the sources of Islamic religious teachings as stated in QS. Al-Ahzab (33): 59, which means:

O Prophet! Say to your wives, daughters, and wives of the believers, "let them cover their veils all over their bodies." This is so that they are easier to identify so that they are not disturbed. And Allah is Most Forgiving, Most Merciful.

\subsection{Porter's Generic Strategy}

First, cost leadership, which emphasizes producing standardized products at low unit costs for pricesensitive consumers. There are 2 (two) types of alternative cost leadership strategies that can be defined. Type 1 (one) is a low-cost strategy. Type 2 (two) is a best-value strategy. Second, differentiation (differentiation) is a strategy that aims at producing a product or service that is considered unique in the industry and is directed at consumers who are relatively priced insensitive (type 3 ). Third, focus (focus), namely producing products or services to meet the needs of a small group of consumers. There are 2 (two) types of alternative focus strategies, namely, type 4 (four) and type 5 (five). Type 4 (four) is a low-cost focused strategy that offers a product or service to a small (small group) of customers at the lowest price available in the market, for example, Pizza Hut, hot dog restaurant, etc. Type 5 (five) is the best value focus strategy that offers a product or service to a small proportion of consumers at the best price available in the market. [6]

\subsection{Business Performance}

According to [5] business is all the activities of institutions that produce goods or provide important services, and are needed in everyday life. Business is an activity that is carried out by people; individually or collectively; by making/providing and selling goods/services, to meet the needs, desires of the market, consumers, to obtain results, within a certain period.

Performance is the result of a business that entrepreneurs have done in the past and is used as a measure of work performance using certain assessment methods [5]. Furthermore, [7] stated that the company's performance can be seen from the level of sales, the level of profit, the return on capital, the rate of turnover, and the market share it achieves. So that performance refers to the level of achievement in a certain period time, that is, performance is very decisive in the development and survival of the company.

\section{RESEARCH METHODOLOGY}

The research approach used is a case study with a qualitative descriptive research method. According to [8] qualitative research methods are methods based on the philosophy of postpositivism used to examine the conditions of natural objects. The researcher as a key instrument, the data collection technique is done in a triangulation (combined) manner, the data analysis is inductive/qualitative and the results of qualitative research emphasize meaning (can only be stated in speech/language) rather than generalization.

Data collection techniques use primary data, namely data obtained directly from the first source (sources) either from individuals/individuals who are directly related to the object of research or existing problems. The analysis technique uses the technical analysis of [9] which is divided into 5 (five) phases, namely (1) compiling, (2) disassembling, (3) reassembling (and arraying), (4) interpreting, and (5) concluding.

\section{RESULTS AND DISCUSSION}

\subsection{Strategies Used in The Azky Collection Hijab Business}

Azky Collection is one of the small businesses in Bungah District, Gresik Regency that implements a focus-differentiation strategy. Small businesses are businesses that are independently owned and operate in a non-dominant place, which generally have few workers, limited capital investment, and low sales [10] More clearly, small (industrial) businesses are business units in the manufacturing sector with a workforce of between 5-19 people.

Azky Collection as a small business has a workforce of between 5 - 19 people spread across several areas in Gresik Regency, has few products, has a clearer customer base, and a specific geographical area. This small business owner also maintains a close relationship with his customers, which allows him to detect shifts in customer wants and needs. So that to keep his customers as a longterm goal, he uses a generic strategy of differentiation focus, namely a focus on the best value that aims to offer a small group of consumers a product or service that meets their tastes and demands better than competing products.

The focus-differentiation strategy is the best value focus strategy that aims to offer a small group of consumers a product or service that meets their tastes and demands better than competing products. Based on the analysis obtained, the attributes of the implementation of the generic strategy of 
differentiation-focus on the Azky Collection SME can be seen in the informants' statements which contain keywords: product development, market development, and innovation as the main strategy.
More details about each attribute can be seen in table 1 .

TABLE 1. Meanings and Themes of the Azky Collection Strategy

\begin{tabular}{|c|c|c|c|}
\hline Informants & Meaning & Attributes Theme & Explanation \\
\hline $\mathrm{HJ}$ & Adding products & \multirow{6}{*}{$\begin{array}{l}\text { Product } \\
\text { development }\end{array}$} & \multirow{6}{*}{$\begin{array}{l}\text { Strategy by developing new } \\
\text { products for existing markets. }\end{array}$} \\
\hline $\mathrm{HJ}$ & Price advantage & & \\
\hline $\mathrm{HJ}$ & Values & & \\
\hline $\mathrm{HJ}$ & Vision & & \\
\hline HJ & Competence & & \\
\hline $\mathrm{HJ}$ & Motivation & & \\
\hline $\mathrm{HJ}$ & Operational & \multirow{3}{*}{$\begin{array}{l}\text { Market } \\
\text { development }\end{array}$} & \multirow{3}{*}{$\begin{array}{l}\text { Strategy by utilizing a market } \\
\text { share that is larger than the } \\
\text { current market share. }\end{array}$} \\
\hline HJ & Adding to the market & & \\
\hline HJ & Additional Services & & \\
\hline $\mathrm{HJ}$ & Innovation models & \multirow[t]{3}{*}{ Innovation } & \multirow{3}{*}{$\begin{array}{l}\text { Strategy by developing new } \\
\text { products and processes. }\end{array}$} \\
\hline HJ & Product innovation & & \\
\hline $\mathrm{HJ}$ & Material innovation & & \\
\hline
\end{tabular}

Source: Researcher Process (2020)

One form of the implementation of the generic differentiation-focus strategy carried out by the Azky Collection is by making syar'i hijab products, in addition to the standard hijab which has been produced for a long time, this is done because the syar'i hijab which is currently widely popular and has become almost a necessity. throughout Indonesia, without exception in Gresik, as a place of production.

For general strategy, as a short-term or annual goal, Azky Collection uses product development, market development, and innovation strategies to retain its customers. The three strategies were chosen to meet different consumer needs with the same focus. This is mainly because the hijab is also a part of fashion for women or Muslim women who always change models with different tastes as their needs.

Based on the meaning of each theme attribute that explains the implementation of the differentiationfocus strategy on the veil mentioned above, it can be seen that the generic strategy and main strategy are an integral or inseparable part of strategic management applications as an effort to meet the company's long and annual or short-term goals. Especially the main strategy in its implementation, much influenced by the company's internal and external environment before it becomes a policy, for later control and evaluation.

\subsection{The Effect of Strategy on Increasing Business Performance of Azky Collection}

Based on the analysis obtained, the attributes of the business performance theme of the Azky Collection UKM can be seen in the informants' statements which contain the keywords: internal improvement and external improvement. More details about each attribute can be seen in table 2 .

TABLE 2. Meanings and Attributes of Themes About Business Performance

\begin{tabular}{|c|c|c|c|}
\hline Informants & Meaning & Attributes Theme & Explanation \\
\hline HJ & Increase in Total sales & \multirow[t]{3}{*}{ Internal increase } & \multirow{3}{*}{$\begin{array}{l}\text { increase Level of } \\
\text { achievement from within } \\
\text { the company. }\end{array}$} \\
\hline HJ & Increased income & & \\
\hline HJ & $\begin{array}{l}\text { Increasing the number of } \\
\text { means of production }\end{array}$ & & \\
\hline HJ & Increase in marketing facilities & \multirow[t]{2}{*}{ Increase external } & \multirow{2}{*}{$\begin{array}{l}\text { The level of achievement } \\
\text { from outside the company. }\end{array}$} \\
\hline HJ & Awards & & \\
\hline
\end{tabular}

Source: Researcher Process (2020) 
Measuring company performance is one of the important actions that companies must take because these measurements can be used to assess the company's success in gaining profits. Performance measurement is a process carried out to identify and assess (measure) the implementation and results of work activities that are being and have been carried out by each party in the company within a certain period, which includes: activity achievement levels, implementation changes, problems and obstacles faced in implementing activities. Measurement and measurement of business performance have several ways, bases, and benchmarks, which are used according to needs.

Through performance measurement, the results of the implementation of activities can be known, corrective steps can be made immediately, and measures can be taken and policies can be taken if an error or deviation occurs. Also, performance measurement must describe the processes and strategies in the company, the measurement will make a real strategy and always be a concern. Performance measurement must meet 4 criteria, namely: must be able to start and end, must be able to describe internal and external interests, must be able to accommodate cost-based and not cost-based units, must include quantitative and qualitative aspects.

The factors that cause business performance to be good, consist of the achievement of a company or business goals (Firm's Goals), management skills or expertise (Management Skill), entrepreneur's ability (Entrepreneur's ability), and other factors [11].

In general, business performance is formed or influenced by the company's ability in its operational activities, namely selling goods or services, making profits, to increase its assets [12]. The company's ability is supported by the managerial ability of the company's management, and other parties who support or are related to management and company operational activities, as well as external parties, some of which are: government, suppliers, society, and financial institutions.

However, the performance of the business or company in small businesses; Apart from several factors as mentioned above, the individual owner of the company is very dominant in influencing business performance. This is because of the special characteristics in small business management: all areas of work in the small business; company work area, management; accessible or accessible to individual small business owners [10].

Companies carry out business activities aimed at producing and selling goods or services. Thus it can be said that the ability of a company or business is measured by its ability to achieve its objectives, namely producing and selling goods and services [13] Business effectiveness is the key to the success of an organization, as measured by the number and sales results achieved.

Based on the results of the interview, it can be seen that performance is part of the way to control and evaluate the selected strategic policies. The choice of differentiation-focus strategy on the Azky Collection is proven to have a positive effect in the form of a significant increase in the number of sales of hijab, it can be seen from the comparison of the number of hijab salesmen, which amounted to 2: 1 with a higher syar'i hijab, more details about the performance picture experienced. significant increase by the Faiz Collection can be seen in Figure 1.1 below. 


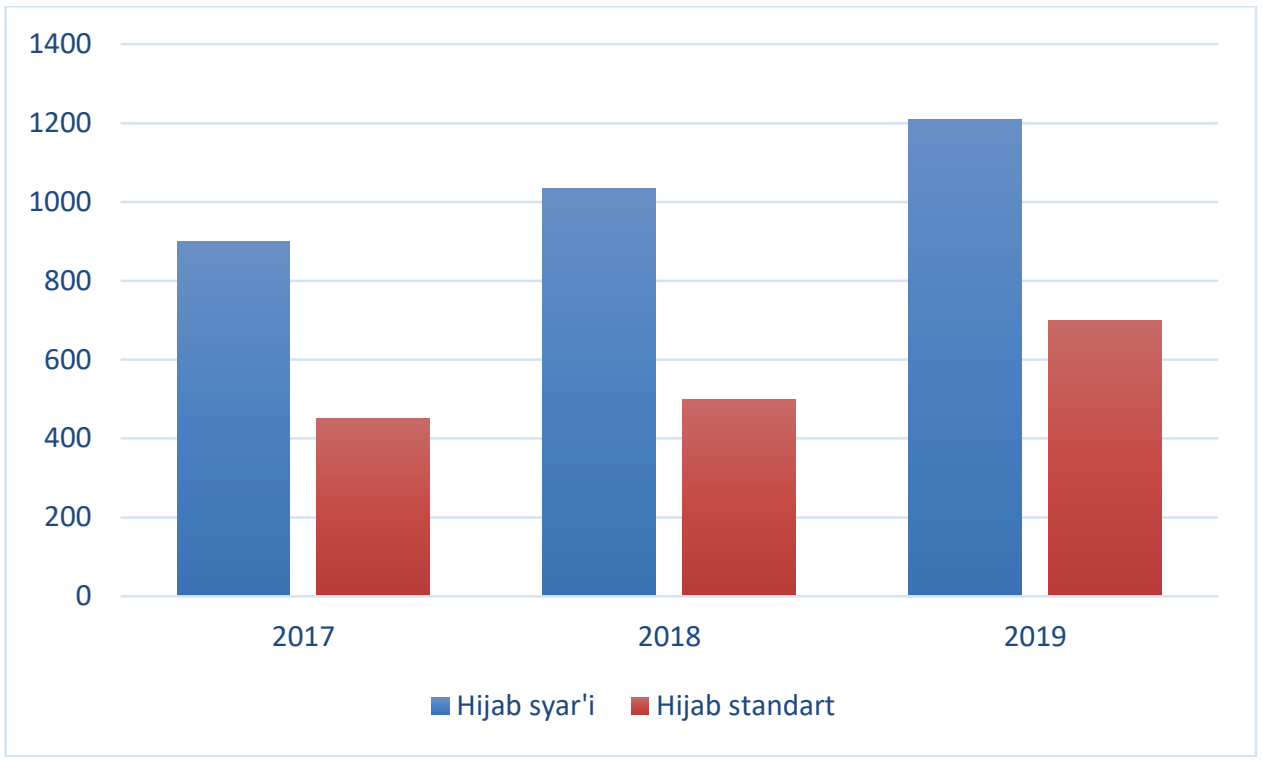

FIGURE 1. Azky Collection Sales Chart (Researcher Process, 2020)

Figure 1above indicates that currently, the Azky Collection is performing well with the implementation of a good strategy, through a clear and targeted strategy and sensitivity to changes in the external environment it does. The success of this performance is also inseparable from the role of the government, namely the Office of Cooperatives, Micro Enterprises, Industry and Trade in Gresik Regency in the form of facilitation and assistance in the form of tools and encouragement in the form of the UKM Award as motivation for the hijab UKM to continue to develop their business.

\section{CONCLUSION}

Based on the results of research and discussion conducted by researchers, the following conclusions can be drawn that the strategy used by the Azky Collection is a focused differentiation strategy using product development, market development, and innovation as the main strategy. The effect of strategy selection on business performance, one of which can be seen is the increase in the number of sales which reached 2 (two) times more than the standard hijab. This is because the Azky Collection follows market tastes which tend to demand syar'i hijab.

\section{REFERENCES}

[1] F. El Guindi, Jilbab: Antara kesalehan, kesopanan dan perlawanan, Jakarta: serambi, 2005.

[2] J. A. Parnell, "Strategic Clarity, Business Strategy and Performance," Journal of Strategy and Management, vol. 3 , no. 4, pp. 302-324, 2010.

[3] M. o. R. o. t. R. o. Indonesia, "Al Qur'an Terjemah Edisi Motivasi," Tiga Serangkai, Solo, 2012.

[4] S. Prabuningrat, Sosok Wanita Muslimat (Pandangan Seorang Artis), Yogyakarta: Tiara Wacana Yogya, 1997.

[5] Jatmiko, Pengantar Bisnis, Malang: UMM Press, 2014.

[6] J. A. R. Pearch, Manajemen Strategi: Formulasi, Implementasi dan Pengendalian, Jakarta: Salemba Empat, 2016.

[7] G. Jauch, Manajemen Strategi dan Kebijakan Perusahaan, Jakarta: Erlangga, 2000.

[8] Sugiyono, Metode Penelitian Kuantitatif, Kualitatif dan R\&D, Bandung: Alfabeta, 2009.

[9] R. K. Yin, Studi Kasus: Desain dan Metode, Jakarta: Rajawali Press, 2009.

[10] A. M. H. H. E. Vernon, Introduction to Modern Business, United Stated of America: Prenctice Hall, Inc, 1981. 
[11] A. P. Lambing, Entrepreneurship, New Jersey: Prenctice Hall, Inc, 2003.

[12] A. F. J. S. Steiner, Business, Government and Society A Manajerial Perspective, United State of America: McGraw-Hill Companies, 2000 .

[13] J. J. Lerner, Introduction to Business Organization and Management, Singapore: McGraw-Hill Book Co, 1986. 